\title{
Anxiety, depression and coping behaviors with pain in cancer patients who are aware or unaware of their cancer
}

\author{
Tanısını bilen ve bilmeyen kanser hastalarının anksiyete, \\ depresyon ve ağrı ile başa çıkma davranışları
}

\section{Gülcan GÜLEÇ, Sacit GÜLEÇ, ${ }^{2}$ Dilek CEYHAN, ${ }^{3}$ Muhtelime BAHAR, ${ }^{4}$ Soner ÖZDEMIR ${ }^{5}$}

\begin{abstract}
Summary
Objectives: This study aimed to investigate whether there are differences in depression, anxiety, pain and styles of coping with pain between cancer patients with and without awareness of their cancer diagnosis.

Methods: In this study, 30 cancer patients aware of their diagnosis and 30 cancer patients unaware of their diagnosis, all of whom visited a clinic for pain treatment, were enrolled in this study. A sociodemographic information form, a questionnaire comprising questions about pain severity and related variables, Hospital Anxiety Depression Scale, and the Pain Coping Questionnaire were administered to the patients.

Results: No significant association was observed between the patients with awareness or unawareness of cancer with respect to anxiety, depression, pain severity, or coping with pain. Pain intensity was significantly associated with depression in both the patient groups.

Conclusion: The study enrolled patients who were admitted for pain treatment, and the sampling group was small. However, this is the first study to investigate the effects of the awareness of cancer diagnosis on pain and its management.

Keywords: Anxiety; cancer; depression; diagnosis; pain.

\section{Özet}

Amaç: Bu çalışmada, tanısını bilen ve bilmeyen kanser hastaları arasında depresyon, anksiyete, ağrı ve ağrı ile başa çıkma tarzında farklııık olup olmadığının araştırııması amaçlamıştır.

Gereç ve Yöntem: Ağrı kliniğine tedavi için başvuran, tanısını bilen 30 ve tanııını bilmeyen 30 kanser hastası çalışmaya alındı. Ağrı şiddeti ve ağrı ile ilişkili değişkenleri sorgulayan sosyodemografik bilgi formu, Hastane Anksiyete Depresyon Ölçeği, Ağrı ile Başa Çıkma Ölçeği uygulandı.

Bulgular: Tanısını bilen ve bilmeyen kanser hastaları arasında anksiyete, depresyon, ağrı şiddeti veya ağrı ile başa çıkma tarzı açısından anlamlı bir farklıık bulunamadı. Ağrı şiddeti her iki grupta da depresyon ile anlamlı düzeyde ilişkiliydi.

Sonuç: Çalışmaya, ağrı tedavisi için başvuran küçük bir örneklem grubu dahil edilmiştir. Fakat çalışmamız kanser tanısını bilmenin ağrı ve ağrı tedavisi üzerindeki etkilerini araştıran ilk araştırmadır.
\end{abstract}

Anahtar sözcükler: Anksiyete; kanser; depresyon; tanı; ağrı.

\section{Introduction}

Cancer is an important public health care problem because of its increasing incidence due to the prolongation of human life. ${ }^{[1]}$ Psychological problems in cancer patients are expected to varying degrees. Occasionally, these problems can be part of the reaction to a cancer diagnosis in patients. However, the psychological problems may be ongoing in most patients, which leads to negative consequences, such as discontinuation of therapy, difficulties in controlling symptoms, delays in hospitalization and negative treatment compliance. ${ }^{[2]}$ The rates of psychiatric morbidity in cancer patients have been reported to be between $9-60 \%$, although studies using stan-

\footnotetext{
'Department of Pschiatry, Eskişehir Osmangazi University Faculty of Medicine, Eskişehir, Turkey

${ }^{2}$ Department of Algology, Eskişehir Osmangazi University Faculty of Medicine, Eskişehir, Turkey

${ }^{3}$ Department of Anesthesiology and Reanimation, Eskişehir Osmangazi University Faculty of Medicine, Eskişehir, Turkey

${ }^{4}$ Habib Edip Törehan Vocational and Technical High School, Eskişehir, Turkey

${ }^{5}$ Department of Psychiatry, Osmaniye State Hospital, Osmaniye, Turkey
}

Submitted (Başvuru tarihi) 11.02.2017 Accepted after revision (Düzeltme sonrası kabul tarihi) 23.06.2017 Available online date (Online yayımlanma tarihi) 04.10.2017

Correspondence: Dr. Sacit Güleç. Eskişehir Osmangazi Üniversitesi Tıp Fakültesi, Algoloji Bilim Dalı, Eskişehir, Turkey.

Phone: +90 - 222 - 2392979 e-mail: sgulec@ogu.edu.tr

(c) 2017 Turkish Society of Algology 
dardized interviews and diagnostic criteria determined a rate of $10-30 \% .{ }^{[3]}$ Anxiety and depression are the most common psychiatric disorders in cancer

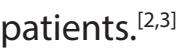

More than $50 \%$ of cancer patients with metastasis and more than $90 \%$ of patients with advanced cancer experience pain. Cancer pain has a negative impact on the patient's physical and mental status and sociability; thus, it impairs the quality of life and constitutes a vicious circle. ${ }^{[4]}$ It has been suggested that a cancer patient views pain as an indicator of his/her disease progression and a sign that death will inevitably occur. These bad thoughts lead to hopelessness and despair in patients. ${ }^{[5]}$

Depression develops more frequently in patients who have experienced severe pain than in patients with less pain, and depression has been reported to increase the pain..$^{[6,7]}$ Cancer pain is usually considered within the biomedical perspective, but recent studies have investigated the role of coping with cancer pain. ${ }^{[8]}$ However, nearly all of these studies have been performed on patients who were aware of their cancer diagnosis. It should be noted that there are cultural differences in the ways in which patients are informed about "bad news". In family centered cultures in particular, a patient may not be told about the cancer diagnosis due to the family's wishes to protect the patient. ${ }^{[2,6-10]}$ Certain studies conducted in these cultures found the prevalence of psychiatric disorders in cancer patients who are aware of their cancer diagnoses was increased. ${ }^{[11,12]}$ In one study, a strong correlation between anxiety, depression and the awareness of the diagnosis was reported. ${ }^{[3]}$ However, it has also been reported that if a patient knows what is happening to him/her, anxiety is reduced and skills for coping with stress are increased; $;{ }^{[13]}$ thus, the patient may accept the reality of his/her diagnosis and become more able to cooperate with health professionals and family members or caregivers. ${ }^{[14]}$ New evidence is necessary to determine whether awareness of the cancer diagnosis is advantageous in different cultural populations.

This study aimed to investigate whether there are differences in depression, anxiety, pain and styles of coping with pain in cancer patients who are aware or unaware of their cancer diagnosis.

\section{Materials and Methods}

\section{Participants}

Sixty consecutive cancer patients (30 patients were aware of their cancer and 30 patients were unaware of their disease) who were admitted to algology outpatient clinics were enrolled in this study. During history taking patients were questioned about their consultation, and referral and whether they know their diagnosis. Accordingly the patients were divided into two groups whether they know that they have a cancer. First 30 patients who knows that they have a diagnosis of cancer included in the "aware group" and 30 patients with not awair of their diagnosis as "unaware group". The patients provided informed consent, and the study was approved by the ethics committee.

Table 1 shows the distribution of cancer diagnoses according to the groups of patients participating in the study.

\section{Measures}

A sociodemographic data form, a questionnaire assessing pain and associated variables, the Karnofsky Performance Scales (KPO), the Hospital Anxiety and Depression Scales (HADS), the Visual Analog Scale (VAS), and the Pain Coping Questionnaire (PCQ) were assessed for each patient.

The Hospital Anxiety and Depression Scale (HADS). The HADS was developed by Zigmond and Snaith ${ }^{[15]}$ to determine the risk, level and severity of anxiety and depression. The validity and the reliability of the scale were adjusted to Turkey by Aydemir and colleagues. ${ }^{[16]}$ This scale is often used for physically ill patients and patients who are referred to primary health care services. A cut-off point of 10 for the anxiety subscale and a cut-off point of 7 for the depression subscale have been accepted for Turkey.

The Pain Coping Questionnaire (PCQ). The PCQ was developed by Kleinke ${ }^{[17]}$ to reveal pain-specific affective behaviors. The PCQ and its validity and reliability have been adjusted to Turkey. ${ }^{[18]}$ The PCQ consists of four subgroups, including helpnessless, conscious cognitive attempts, medical remedies and self-management.

The Karnofsky Performance Status Scale (KPSS). The 
Table 1. Distribution of cancer diagnosis of patients enrolled in study

\begin{tabular}{|c|c|c|c|c|c|}
\hline \multicolumn{3}{|c|}{ Aware group $(n=30)$} & \multicolumn{3}{|c|}{ Unaware group $(n=30)$} \\
\hline Diagnosis & $\mathbf{n}$ & $\%$ & Diagnosis & $\mathbf{n}$ & $\%$ \\
\hline Head and neck cancer & 9 & 30.0 & Head and neck cancer & 1 & 3.3 \\
\hline Bronchopulmonary cancer & 7 & 23.3 & Bronchopulmonary cancer & 7 & 23.3 \\
\hline Multiple myeloma & 1 & 3.3 & Colon-rectum cancer & 4 & 13.3 \\
\hline Colon-rectum cancer & 4 & 13.3 & Breast Cancer & 1 & 3.3 \\
\hline Malign mesothelioma & 3 & 10.0 & Malign mesothelioma & 1 & 3.3 \\
\hline Breast cancer & 2 & 6.7 & Pancreatic cancer & 7 & 23.3 \\
\hline Pancreatic cancer & 3 & 10.0 & Cervical cancer & 2 & 6.7 \\
\hline \multirow[t]{4}{*}{ Cervical cancer } & 1 & 3.3 & Renal cancer & 4 & 13.3 \\
\hline & & & Prostate cancer & 1 & 3.3 \\
\hline & & & Bladder cancer & 1 & 3.3 \\
\hline & & & Malignant Melanoma & 1 & 3.3 \\
\hline
\end{tabular}

KPSS was developed by Karnofsky and Burchenal ${ }^{[19]}$ for evaluating a patient's physical performance. A score of 100 indicates healthy and a score of 0 indicates death, and each 10-point interval corresponds to a situation.

The Visual Analog Scale (VAS). This scale measures the severity of pain in patients. This scale is $10 \mathrm{~cm}$ long, and the two ends on the vertical and horizontal lines have different names $(0=$ no pain, $10=$ most severe pain). Patients are asked to mark a point that corresponds to the severity of pain he/she feels, and the distance between the lowest endpoint (0) and the point marked by the patient are measured. The measured numeric value indicates the patient's pain severity. ${ }^{[20]}$

A questionnaire has been designed to evaluate the impact of pain on the physiological, psychological and social well-being of a patient. The questionnaire consists of questions regarding the distress caused by the pain, the patient's thoughts on pain control and future pain severity, the patient's satisfaction with pain treatment and the severity of the secondary symptoms of pain treatment and cancer treatment (secondary symptoms include nausea, vomiting, constipation, loss of appetite, fatigue, pruritus, nightmare, sweating, thinking difficulties and insomnia). Patients were asked to mark numbers between 0 - 10 for the subjective assessment. Marking 0 indicates no symptoms and 10 indicates the most acute symptom. The questionnaire also has a question that evaluates the outcomes of pain treatment as " 0 " or " no pain relief", to " 100 " or "complet pain relief".

\section{Data analysis}

The Kalmogorov-Smirnov test was performed for data obtained from the sample groups. Only pain relief by treatment, the "conscious cognitive interventions" subscale of the Coping with Pain Scale and the "depression" subscale of the Hospital Anxiety scale were normally distributed. Therefore, a Mann-Whitney $U$ test was used for the comparisons of numerical data. A t test was performed for the comparison of the average age of the groups. A $X^{2}$ test was performed for the comparison of the values obtained by counting, and Spearman correlation analysis was applied where necessary. $P<0.05$ was considered statistically significant.

\section{Results}

No significant differences were found in gender, educational level, marital status, living place, therapy, metastases or the stage of the cancer between the group that was aware of the diagnosis $(\mathrm{N}=30)$ and the group that was not aware $(\mathrm{N}=30)$. The group that was aware of the diagnosis was younger than the group that was unaware of the diagnosis, but this difference was not statistically significant. Comparisons of the sociodemographic findings are shown in Table 2.

The severity of the symptoms, such as disease dura- 
Table 2. Comparison of sociodemographic and clinical data based on groups who are aware and unaware of diagnosis

\begin{tabular}{|c|c|c|c|c|c|c|}
\hline & \multicolumn{2}{|c|}{ Aware group $(n=30)$} & \multicolumn{2}{|c|}{ Unaware group $(n=30)$} & \multirow[t]{2}{*}{$\mathbf{x}^{2}$} & \multirow[t]{2}{*}{$\mathbf{P}$} \\
\hline & $n$ & $\%$ & $\mathbf{n}$ & $\%$ & & \\
\hline \multicolumn{7}{|l|}{ Education } \\
\hline $0-5$ years & 18 & 60.0 & 24 & 80.0 & \multirow[t]{2}{*}{1.98} & \multirow[t]{2}{*}{$>0.05$} \\
\hline 6 years and above & 12 & 40.0 & 6 & 20.0 & & \\
\hline \multicolumn{7}{|l|}{ Gender } \\
\hline Female & 14 & 46.7 & 15 & 50 & \multirow[t]{2}{*}{0.00} & \multirow[t]{2}{*}{$>0.05$} \\
\hline Male & 16 & 53.3 & 15 & 50 & & \\
\hline \multicolumn{7}{|l|}{ Marital status } \\
\hline Married & 24 & 80.0 & 26 & 86.7 & \multirow[t]{2}{*}{0.12} & \multirow[t]{2}{*}{$>0.05$} \\
\hline Single/Widow & 6 & 20.0 & 4 & 13.3 & & \\
\hline \multicolumn{7}{|l|}{ Location } \\
\hline City & 23 & 76.7 & 19 & 63.3 & \multirow[t]{2}{*}{0.71} & \multirow[t]{2}{*}{$>0.05$} \\
\hline County & 7 & 23.3 & 11 & 36.7 & & \\
\hline \multicolumn{7}{|l|}{ Treatment } \\
\hline No treatment & 4 & 13.3 & 7 & 23.3 & \multirow[t]{4}{*}{1.58} & \multirow[t]{4}{*}{$>0.05$} \\
\hline Chemotherapy & 7 & 23.3 & 6 & 20.0 & & \\
\hline Radiotherapy & 9 & 30.0 & 6 & 20.0 & & \\
\hline Combination & 10 & 33.3 & 11 & 36.7 & & \\
\hline \multicolumn{7}{|l|}{ Metastasis } \\
\hline Yes & 20 & 69.0 & 22 & 73.3 & \multirow[t]{2}{*}{0.01} & \multirow[t]{2}{*}{$>0.05$} \\
\hline No & 10 & 31.0 & 8 & 26.7 & & \\
\hline \multicolumn{7}{|l|}{ Stage of cancer* } \\
\hline Stage 1-2 & 3 & 10 & 1 & 3.3 & \multirow[t]{2}{*}{2.5} & \multirow[t]{2}{*}{$>0.05$} \\
\hline \multirow[t]{2}{*}{ Stage 3-4 } & 27 & 90 & 29 & 96.6 & & \\
\hline & \multicolumn{2}{|c|}{ Mean \pm SD } & \multicolumn{2}{|c|}{ Mean \pm SD } & $\mathbf{t}$ & \\
\hline Age & \multicolumn{2}{|c|}{$55.43 \pm 14.11$} & \multicolumn{2}{|c|}{$59.70 \pm 10.76$} & 2.85 & $>0.05$ \\
\hline
\end{tabular}

SD: Standard deviation.

tion, the KPS score, the pain duration, the pain severity, the patient's satisfaction from pain treatment, constipation, loss of appetite, fatigue, itching, nightmares, sweating, thinking difficulties and insomnia which develop secondary to pain, method of pain management, and cancer treatment type were not statistically different between the two groups. The group that was aware of the cancer diagnosis reported $70 \%(50-80)$ pain relief with the pain treatment, and the other group reported $50 \%(40-80)$ pain relief $(z=-1.1,98 ; P=0.05)$. The severity of nausea $(z=-$ $2.65, \mathrm{P}<0.01)$ and vomiting $(\mathrm{z}=-1.99, \mathrm{P}<0.05)$ was less in the group that was aware of the diagnosis. Comparisons of the pain-related variables in both groups are shown in Table 3.
The severity of anxiety for the aware group and the unaware group was 12 (9.00 to 14.50) and 13.50 (10.00 to 17.25 ), respectively; the severity of depression for these groups was $10.00(7.75-13.00)$ and 11.50 (9.75-15.00), respectively. The severity of depression and anxiety were not different between the groups. The cut-off score for the anxiety subscale of the HADS was 10; the score on this subscale was $\geq 10$ for 21 (70\%) patients who were aware of the diagnosis and $24(80 \%)$ patients who were unaware of the diagnosis ( $\left.P>0.05, x^{2}=0.36\right)$. The cut-off score for the depression subscale of the HADS was 7; 22 (73\%) patients who were aware of the diagnosis and 27 (90\%) patients who did not know the diagnosis had scores $\geq 7\left(P>0.05, x^{2}=1.78\right)$. 
Table 3. Comparison of median, $25 \%$ ve $75 \%$ percentile values of variables related to pain and pain treatment based on groups

\begin{tabular}{lcccc}
\hline & $\begin{array}{c}\text { Aware group (n=30) } \\
\text { Median (25-75\%) }\end{array}$ & $\begin{array}{c}\text { Unaware group (n=30) } \\
\text { Median (25-75\%) }\end{array}$ & U & $\mathbf{P}$ \\
\hline Illness duration-month & $8(5-13.5)$ & $7(5-12)$ & 402.50 & $>0.05$ \\
Karnofsky performance & $70(40-80)$ & $60(40-80)$ & 436.00 & $>0.05$ \\
Pain duration & $3.5(1.87-5.25)$ & $3(1.75-5.5)$ & 423.00 & $>0.05$ \\
Severity of pain (VAS) & $4(2-8)$ & $4.5(2-9)$ & 402.50 & $>0.05$ \\
Pain is giving how much trouble & $6.5(3.75-8)$ & $5(2-8.25)$ & 411.50 & $>0.05$ \\
How much trouble is giving pain to family & $5(4-7.25)$ & $6(3.75-9)$ & 392.50 & $>0.05$ \\
How do you control your pain & $5(3.5-7)$ & $5(3.75-6.25)$ & 413.50 & $>0.05$ \\
What will be your future pain & $1(0-3.25)$ & $1(1-2.25)$ & 437.50 & $>0.05$ \\
How much has changed in the treatment of pain & $70(50-80)$ & $50(40-80)$ & 306.00 & $=0.05$ \\
Satisfaction with pain management & $7(5.75-9.25)$ & $7(6-8.5)$ & 401.00 & $>0.05$ \\
Nausea & $0(0-2.5)$ & $3(1-5)$ & 256.00 & $<0.01$ \\
Vomitting & $0(0-4.5)$ & $2(1-5.5)$ & 296.00 & $<0.05$ \\
Constipation & $4(0-5)$ & $3(1.5-6)$ & 339.00 & $>0.05$ \\
Loss of appetite & $4(0-7)$ & $4(2-8.5)$ & 322.00 & $>0.05$ \\
Fatigue & $5(2-7)$ & $6(2-8)$ & 394.00 & $>0.05$ \\
Itching & $0(0-2)$ & $1(0-2)$ & 369.00 & $>0.05$ \\
Nightmare & $0(0-3.5)$ & $1(0-4)$ & 368.00 & $>0.05$ \\
Sweating & $3(1-5)$ & $2(1-7.5)$ & 419.00 & $>0.05$ \\
Difficulty thinking & $1(0-3)$ & $3(0-5)$ & 333.00 & $>0.05$ \\
Insomnia & $4(1-5)$ & $3(-5.5)$ & 387.00 & $>0.05$ \\
\hline
\end{tabular}

The subscale scores of the PCQ were not significantly different between the groups. However, a helplessness subscale score of 19 (17-22) and a selfcoping subscale score of $23,50(12,75-26,25)$ were the highest scores. The group comparisons for the HADS and the OAU are shown in Table 4.

The severity of pain in the aware group correlated with the pain recovery rate with treatment $(r=-.58$, $P<0.01)$, satisfaction with the pain treatment $(r=-.52$, $P<0.01)$, selfcoping $(r=-.52, P<0.01)$, conscious cognitive interventions $(r=-.48, P<0.01)$, anxiety $(r=-.50$, $\mathrm{P}<0.01)$ and depression $(\mathrm{r}=.32, \mathrm{P}<0.05)$.

The severity of pain in the unaware group correlated with the disease duration $(r=.35, P<0.05)$, the pain recovery rate with treatment $(r=-.48, P<0.01)$, satisfaction with the pain treatment $(r=-.41, P<0.05)$, selfmanagement $(r=-.50, P<0.01)$, conscious cognitive attempts $(r=-.58, P<0.01)$, helplessness $(r=-.35$, $\mathrm{P}<0.01)$, the medical remedies $(r=-.53, P<0.01)$, anxiety $(r=-.50, P<0.01)$ and depression $(r=.42, P<0.05)$.

\section{Discussion}

\section{Anxiety and depression scores}

Anxiety and depression are the most common psychological problems in cancer patients, with prevalence rates varying between 25 and $50 \% .{ }^{[2]}$ The high rate of depression in the present study may have been due to the complaints of pain, in addition to cancer, in all participants. In one study, ${ }^{[21]}$ psychiatric disorders were reported to be infrequent in patients who were unaware of their diagnosis; positive expectations about the results of the treatment might be the cause of this observation. The rate of psychiatric disorders has been reported to be low in patients who were unaware of their diagnosis in a study by Ateşçi et al. ${ }^{[12]}$ However, in that study, the authors reported that patients recognized their cancer diagnosis intuitively or in indirect ways; thus, the negative thoughts attributed to cancer might increase the rate of psychiatric disorders. Several case-control studies have revealed that there is no relationship between the disclosure of a cancer diag- 
Table 4. Comparison of median, $25 \%$ and $75 \%$ percentile values of HADS and PCQ scores based on groups

\begin{tabular}{lcccr}
\hline & $\begin{array}{c}\text { Aware group (n=30) } \\
\text { Median (25-75\%) }\end{array}$ & $\begin{array}{c}\text { Unaware group (n=30) } \\
\text { Median (25-75\%) }\end{array}$ & U & P \\
\hline HADS & $12(9-14.5)$ & $13.5(10-17,25)$ & 338.50 & $>0.05$ \\
$\quad$ Anxiety & $10(7.75-13)$ & $11.5(9.75-15)$ & 339.50 & $>0.05$ \\
$\quad$ Depression & $17(15-25)$ & $23.5(12.75-26.25)$ & 426.00 & $>0.05$ \\
PCQ & $19(17-22)$ & $18.5(16-20)$ & 364.50 & $>0.05$ \\
Self-management & $13(11-17)$ & $15.5(11-18.25)$ & 409.00 & $>0.05$ \\
$\quad$ Helplessness & $16(13-19.5)$ & $16.5(13-21)$ & 429.00 & $>0.05$ \\
$\quad$ Conscious cognitive attempts & & & & \\
$\quad$ Medical remedies & &
\end{tabular}

HADS: Hospital Anxiety and Depression Scale; PCQ: Pain Coping Questionnire.

nosis and mental damage. ${ }^{[9]}$ In fact, in one study, the Beck Depression Inventory scores were significantly lower in patients who recognized their diagnosis. ${ }^{[22]}$ In a study by Tavoli et al., ${ }^{[3]}$ the anxiety and depression scores of the aware patients were $9.1( \pm 4.2)$ and $9.1( \pm 4.1)$, respectively; the anxiety and depression scores of the unaware group were $6.3( \pm 4.4)$ and 7.9 $( \pm 3.6)$, respectively. Statistically significant differences between groups were reported. In our study, both anxiety and depression scores were higher than those reported by Tavoli et al.;.; ${ }^{[3]}$ however, anxiety and depression did not differ between the groups in our study. Our study did not support the hypothesis that more psychiatric disorders are observed in a group that is aware of the cancer diagnosis. In our study, the time of diagnosis was $4.6( \pm 3.0)$ months for the aware group and $4.1( \pm 3.2)$ months for the unaware group. In both groups, the time of diagnosis ranged from 1-12 months with no significant difference between the groups. However, Tavoli et al. ${ }^{[3]}$ reported differences in the patients who experienced pain for a long time and prolonged disease duration. A study by Galloway et al. ${ }^{[23]}$ that enrolled women with breast cancer also supported a correlation between the duration of pain and anxiety or depression. The authors did not find a relation between the severity of pain and anxiety or depression at 3- months follow-up, whereas they did find that pain was related to both anxiety and depression at an18- months follow-up. Recent studies have reported that pain and the severity of pain were significantly associated with depressive and anxiety symptoms. ${ }^{[2,23-27]}$ It has been suggested that anxiety and depression independently contributed to the emergence of mental health and somatic symptoms, ${ }^{[27]}$ pain-aggravated mood disorders. ${ }^{[25]}$ Thus, a significant correlation between physical symptoms, such as pain, and depression and/or anxiety might be more common in depressed cancer patients. ${ }^{[26]}$ However, in some studies, depression was found to be more prominent than anxiety; therefore, pain has been suggested to directly correlate with depression. ${ }^{[2,25]}$

\section{Pain coping scores}

Cancer pain may be observed as both chronic and acute pain. Acute pain develops as a result of tissue damage; hyperactivity of the sympathetic nervous system shows a strong correlation with the level of anxiety, whereas chronic pain is related to depression and vegetative symptoms. ${ }^{[5]}$ Furthermore, in our study, because patients with cancer had suffered from pain for a long time, the severity and duration of the pain correlated with depression.

Studies have shown that patients using adaptive pain coping strategies experience less severe pain and less psychological distress. ${ }^{[8,28]}$ In our study, pain-related coping was not statistically significant between the two groups. The lowest scores in both groups were recorded for the "conscious cognitive attempts" subscale. Consious cognitive attempts are defined as focusing on something instead of the pain and reinterpreting and imagining the sensation of pain. ${ }^{[18]} \mathrm{Pa}$ tients who learn pain coping strategies, such as "conscious cognitive attempts", can live more efficiently, despite pain. ${ }^{[29]}$ The highest scores were obtained on the "coping management" subscale among patients who were unaware of the diagnosis and for the "helpnessless" subscale among patients who were aware of the diagnosis. "Helpnessless", or the feeling of a 
disaster, selective abstraction, overgeneralization, and personalization, indicates cognitive distortions. ${ }^{[18]}$ Learning pain coping strategies has been reported to be important for the correction of pain behavior; thus, it is necessary to rule out negative methods and to strengthen positive coping methods. ${ }^{[18,30]}$

\section{Disclosure of cancer diagnosis}

In addition to medical treatment, cancer patients need psychosocial support to streng their positive pain coping behaviors. It is difficult for a mental health professional to provide psychosocial support a patient who is unaware of the diagnosis. If the physician avoids informing the patient about the diagnosis, the patient may suspect a poor prognosis for his/her cancer. ${ }^{[8]}$ Patients who do not feel adequately informed often feel insecure about receiving help for symptoms due to the lack of information. In addition, insufficient information on the diagnosis, prognosis and treatment options will increase anxiety and doubt. ${ }^{[3]]}$

When terminal stage cancer patients come face to face with death, they exhibit a common medical condition, and treatment options with the potential for toxicity may need to be considered. These treatment options may include standard therapy or experimental approaches, as well as supportive care. ${ }^{[32]}$ In this case, the patient's preference is important. Bioethics supports incorporating patients in their own medical treatments. To rule out a patient's decision in a decisionmaking process is considered an insult against human dignity and autonomy. ${ }^{[33]} \mathrm{Be}-$ ing aware or unaware of his/her diagnosis was not associated with variables related to anxiety, depression, pain intensity or pain treatment; these findings indicate the futility of hiding the diagnosis. Certain individuals may think that the patients in our study were advanced stage patients, and pain might mostly occur in the later stages of cancer. If it is useless to hide the diagnosis over time, not informing the patient about the diagnosis and ruling out the patient's decision in the decisionmaking process take away the patient's rights regarding proper selfassertions. In studies. ${ }^{[2,34-36]}$ In which patients were asked about their preferences regarding their treatment, the patients whose cancer-related distress was low (such as older patients, male, highly educated and childless patients) preferred quality of life; however, patients who were young and who had a child and a more functional health status preferred the prolongation of life. ${ }^{[34]}$ Instead of trying to protect a patient by not informing him/ her about the cancer diagnosis, we should investigate the ways to inform a patient about his/her cancer diagnosis without causing negative consequences.

\section{Limitations}

There are some limitations of this study: i) the study enrolled patients who were admitted for pain treatment; ii) the sampling group was small; and iii) the study's patients were more advanced stage cancer patients. Although a generalization is not appropriate, this is the first study which investigated the impact of knowing a cancer diagnosis on pain and coping with pain, and future studies and trials are necessary.

\section{Conclusion}

In this study, no differences were been found for pain and its associated variables or for anxiety, depression, or coping with pain between patients who were aware of their cancer diagnosis and patients who were unaware. Patients who were unaware of their cancer diagnosis reported less improvement in pain, and more nausea and vomiting.

In many countries, the guidelines are available for informing patients about their cancer diagnosis. In family centered culture in particular, relatives of patients and doctors concerned about talking about a cancer diagnosis. Our study and similar studies will provide scientific data to assuage their concern.

\section{Competing interests}

The authors declare that they have no financial or personal relationships which may have inappropriately influenced them in writing this article.

\section{Conflict-of-interest issues regarding the authorship or article: None declared.}

Peer-rewiew: Externally peer-reviewed.

\section{References}

1. Yıldırım NK, Özkan M, Özkan S, Özçınar B, Güler SA, Özmen V. Meme kanserli hastaların tedavi öncesi ve sonrası anksiyete depresyon ve yaşam kalitesi: Bir yıllık prospektif değerlendirme sonuçları. Nöropsikiyatri Arşivi 2009;46:175-81.

2. Hong JS, Tian J. Prevalence of anxiety and depression and their risk factors in Chi-nese cancer patients. Support Care Cancer 2014;22(2):453-9. 
3. Tavoli A, Mohagheghi MA, Montazeri A, Roshan R, Tavoli Z, Omidvari $S$. Anxiety and depression in patients with gastrointestinal cancer: does knowledge of cancer diag-nosis matter? BMC Gastroenterol 2007;7:28.

4. Kuzeyli Yildirim Y, Uyar M, Fadillioğlu C. Cancer pain and its influence on quality of life. Agri 2005;17(4):17-22.

5. Ozkan S. Psychiatric aspects of pain in cancer patients. Asian Pac J Cancer Prev 2010;11 Suppl 1:113-6.

6. Spiegel D, Bloom JR.Cancer. Pain in metastatic breast cancer. 1983;52(2):341-5.

7. Spiegel D, Sands S, Koopman C. Pain and depression in patients with cancer. Cancer 1994;74(9):2570-8.

8. Prasertsri N, Holden J, Keefe FJ, Wilkie DJ. Repressive coping style: relationships with depression, pain, and pain coping strategies in lung cancer outpatients. Lung Can-cer 2011;71(2):235-40.

9. Miyata H, Tachimori H, Takahashi M, Saito T, Kai I. Disclosure of cancer diagnosis and prognosis: a survey of the general public's attitudes toward doctors and family hold-ing discretionary powers. BMC Med Ethics 2004;5:E7.

10. Back AL, Anderson WG, Bunch L, Marr LA, Wallace JA, Yang $\mathrm{HB}$, et al. Commu-nication about cancer near the end of life. Cancer 2008;113(7 Suppl):1897-910.

11. Herdem S. Kanser hastalarında psikiyatrik komorbidite ve intihar düşüncesi. Doctoral dissertation, Eskişehir Osmangazi University Medical Faculty Psychiatry Department, Eskişehir, Turkey, 2008.

12. Ateşci FC, Oğuzhanoğlu NK, Baltalarli B, Karadağ F, Ozdel O, Karagöz N. Psychi-atric disorders in cancer patients and associated factors. Turk Psikiyatri Derg 2003;14(2):145-52.

13. Şener Ş, Günel N, Akçalı Z, Şenol S, Koçkar Aí. Meme kanserinin ruhsal ve sosyal etkileri üzerine bir çalışma. Klinik Psikiyatri Dergisi 1999;2(4):254-60.

14. Özkan S, Armay Z. Psiko-onkoloji. İstanbul: Form Reklam Hizmetleri; 2007.

15. Zigmond AS, Snaith RP. The hospital anxiety and depression scale. Acta Psychiatr Scand 1983;67(6):361-70.

16. Aydemir Ö, Güvenir T, Küey L, Kültür S. Hastane Anksiyete ve Depresyon Ölçeği Türkçe formunun geçerlilik ve güvenilirliği. Türk Psikiyatri Dergisi 1997;8(4):280-7.

17. Kleinke CL. How chronic pain patients cope with pain: Relation to treatment out-come in a multidisciplinary pain clinic. Cognitive Therapy and Research 1992;16(6):669-85.

18. Karaca S, Demir F, Aşkın R, Şimşek İ. Ağrı ile başa çıkma ölçeği geçerlilik ve gü-venilirliği. 5. Türk-Alman Fiziksel Tıp ve Rehabilitasyon Kongresi. Antalya: 1996.

19. Karnofsky DA, Burchenal JH. The Clinical Evaluation of Chemotherapeutic Agents in Cancer. In: MacLeod CM, editor. Evaluation of Chemotherapeutic Agents. New York: Columbia University Press; 1949. p. 196.

20. Price DD, McGrath PA, Rafii A, Buckingham B. The validation of visual analogue scales as ratio scale measures for chronic and experimental pain. Pain 1983;17(1):45-56.

21. Alexander PJ, Dinesh N, Vidyasagar MS. Psychiatric morbidity among cancer pa-tients and its relationship with awareness of illness and expectations about treatment outco- me. Acta Oncol 1993;32(6):623-6.

22. Ersoy MA. Kanser hastalarında inkar, tedavi ekibiyle ilişki, bilgilendirme, kanser tanısının söylenmesi, alternatif tedavi yöntemlerine başvurma ve depresyon ilişkisinin incelenmesi. Psikiyatri Psikoloji Psikofarmakoloji (3P) Dergisi 2000;8(1):17-26.

23. Galloway SK, Baker M, Giglio P, Chin S, Madan A, Malcolm R, et al. Depression and Anxiety Symptoms Relate to Distinct Components of Pain Experience among Pa-tients with Breast Cancer. Pain Res Treat 2012;2012:851276.

24. Nuhu FT, Odejide OA, Adebayo KO, Yusuf AJ. Psychological and physical effects of pain on cancer patients in Ibadan, Nigeria. Afr J Psychiatry (Johannesbg) 2009;12(1):64-70.

25. Ko HJ, Seo SJ, Youn CH, Kim HM, Chung SE. The Association between Pain and Depression, Anxiety, and Cognitive Function among Advanced Cancer Patients in the Hospice Ward. Korean J Fam Med 2013;34(5):347-56.

26. Teunissen SC, de Graeff A, Voest EE, de Haes JC. Are anxiety and depressed mood related to physical symptom burden? A study in hospitalized advanced cancer patients. Palliat Med 2007;21(4):341-6.

27. Brown LF, Kroenke K, Theobald DE, Wu J, Tu W. The association of depression and anxiety with health-related quality of life in cancer patients with depression and/or pain. Psychooncology 2010;19(7):734-41.

28. Fischer DJ, Villines D, Kim YO, Epstein JB, Wilkie DJ. Anxiety, depression, and pain: differences by primary cancer. Support Care Cancer 2010;18(7):801-10.

29. Madenci E, Herken H, Yağız E, Keven S, Gürsoy S. Kronik ağrılı ve fibromiyalji sendromlu hastalarda depresyon düzeyleri ve ağrı ile başa çıkma becerileri. Türk Fiz Tıp Rehab Derg 2006;52(1):19-21.

30. Okyayuz UH. Ölümcül hastalık tanısı almak: bir yaşam krizi kötü haber verilmeli mi? Kriz Dergisi 2003;11(3):29-35.

31. Mystakidou K, Parpa E, Tsilika E, Katsouda E, Vlahos L. Cancer information dis-closure in different cultural contexts. Supportive Care in Cancer 2004;12(3):147-54.

32. Meropol NJ, Egleston BL, Buzaglo JS, Benson AB $3^{\text {rd }}$, Cegala DJ, Diefenbach MA, et al; CONNECT Study Research Group. Cancer patient preferences for quality and length of life. Cancer 2008;113(12):3459-66.

33. McCabe MS, Wood WA, Goldberg RM. When the family requests withholding the diagnosis: who owns the truth? J Oncol Pract 2010;6(2):94-6.

34. Stiggelbout AM, de Haes JC, Kiebert GM, Kievit J, Leer JW. Tradeoffs between quality and quantity of life: development of the QQ Questionnaire for Cancer Patient Attitudes. Med Decis Making 1996;16(2):184-92.

35. Voogt E, van der Heide A, Rietjens JA, van Leeuwen AF, Visser AP, van der Rijt CC, et al. Attitudes of patients with incurable cancer toward medical treatment in the last phase of life. J Clin Oncol 2005;23(9):2012-9.

36. Koedoot CG, de Haan RJ, Stiggelbout AM, Stalmeier PF, de Graeff A, Bakker PJ, et al. Palliative chemotherapy or best supportive care? A prospective study explaining patients' treatment preference and choice. Br J Cancer 2003;89(12):2219-26. 